\title{
In vivo Growth Inhibition of Sarcoma-180 Cells by a $\beta$-Glucan from the Mushroom Ganoderma lucidum
}

\author{
Man-Deuk Han*, Yong Hyun Kim and Wan Jong Kim \\ Department of Biology, College of Natural Science, Soonchunhyang University, Chungnam 336-745, Korea
}

Received April 8, 2014 /Revised May 28, 2014 /Accepted July 22, 2014

\begin{abstract}
Mushroom-derived $\beta$-glucan, a polysaccharide (GLP) isolated from the mycelium of Ganoderma lucidum, was previously shown to have inhibitory effects against tumor-bearing mice in vivo. We investigated the apoptotic effect of mushroom-derived $\beta$-glucan in a sarcoma-180 tumor cell- bearing mice model using an ELISA to determine the levels of tumor necrosis factor-a (TNF-a) in the mice. The morphology of the tumor cells was assessed with transmission electron microscopy (TEM). GLP was injected into the tumor-bearing mice at a dose (i.p.) of $20 \mathrm{mg} / \mathrm{kg}$ for 10 days. After 30 days, the tumor mass from the inguinal region was collected, weighed, and assayed using TEM and a TNF-a ELISA kit. The tumors that developed in the mice treated with GLP were $71.4 \%$ smaller than those in the control group, showing the ability of GLP to inhibit tumor growth. The levels of TNF-a in the serum of the sarcoma-180 bearing mice were 12 times greater than in the serum of the nonbearing tumor mice. An ultrastructural study demonstrated that the GLP-treated sarcoma-180 tumor cells were condensed, with rearranged chromatin. In addition, the marginated chromatin in nucleus induced the nuclear compartment, and there were many vacuolization in the cell. GLP could be an effective apoptosis-inducing compound in sarcoma-type cancers.
\end{abstract}

Key words : Apoptosis, $\beta$-glucan, Ganoderma lucidum, Sarcoma-180 cells, tumor necrosis factor-a

\section{서 론}

영지(Ganoderma lucidum)는 동양에서 수 세기 동안 알레르 기, 관절염, 기관지염, 위장염, 고혈압, 당료, 만성간염, 간장질 환, 신장염, 신경쇠약증(neurasthenia), 불면(insomnia), 피부 경화증(scleroderma), 염증 및 암 등과 같은 사람의 질병을 치 료하기 위해 사용된 약용버섯이다[22]. 영지의 주요 약리적 활 성 성분은 다당류(polysaccharides), ganoderic acid (triterpene) 및 아데노신 등이며, 이 가운데 다당류인 $\beta$-glucan이 가장 많 이 연구된 생리활성 물질이다[2, 7, 12, 17, 20]. 트리터펜 (Triterpene)류 분자에 속하는 ganoderic acids는 항종양 및 항 -HIV-1 활성을 가지고 있으며 $[18,27]$, 최근까지 100여종이 영 지로부터 분리되었다[21]. 영지의 다당류-펩타이드 성분은 다 양한 물리 화학적인 특성을 갖고 있으며 $[6,23]$, 그 특성에 따라 사람 암세포에서 혈관 신 생성을 억제하는 것이 보고되었다 [3]. 또한 다당류의 조성 및 주요 사슬의 결합 형태뿐만 아니라 결합된 단백질이나 펩타이드 같은 비 탄수화물성분의 결합비 율에 따라 항원성에 차이가 있어 암세포 증식억제효과가 다르

\section{*Corresponding author}

Tel : +82-41-530-4702, Fax : +82-41-530-1256

E-mail : mdhan@sch.ac.kr

This is an Open-Access article distributed under the terms of the Creative Commons Attribution Non-Commercial License (http://creativecommons.org/licenses/by-nc/3.0) which permits unrestricted non-commercial use, distribution, and reproduction in any medium, provided the original work is properly cited
게 나타난다[26]. 영지의 다당류 가운데 $\beta$-glucan은 면역계를 구성하는 항원제시세포(antigen-presenting cells), $\mathrm{T}$ 림프구 및 B 림프구 $[1,26], \mathrm{NK}$ 세포[4], 호중구[13] 및 수지상 세포[2, 15] 인자들을 조절하는 기능이 있다. 버섯의 다당류가 암세포 를 억제하는 기전에 대한 연구로는 Wang 등이 영지에서 분리 한 다당류가 암세포 주기를 조절하고 에폽토시스(apoptosis) 를 유도하여 직접적으로 생장을 억제한다고 보고하였다[24]. Chow 등은 구름버섯(Trametes versicolor)에서 추출한 다당류펩타이드 복합체(PSP)가 MAD-MB-231 유방암 세포의 p21 유 전자 발현을 증가시키고, 세포주기 조절단백질인 cyclin D1 단백질의 발현을 감소시켜 유방암세포의 증식을 유의성 있게 억제됨을 보고하였다[5]. Li 등은 상황버섯(Phellinus linteus)에 서 분리한 단백다당류에 의해 사람의 결장암 세포주 SW-480 에서 bcl-2의 발현감소, cytochrome c 방출의 증가 및 cyclin $\mathrm{B} 1$ 발현을 감소시켜 $\mathrm{G} 2 / \mathrm{M}$ 세포주기에서 더 이상 세포 분열을 하지 않고 에폽토시스를 유도하는 것으로 보고하였다[14]. 또 한 Zhang 등은 복령 (Poria cocos)에서 분리된 수용성 B-glucan 은 사람 유방암 세포주 MCF-7에 세포주기 정지와 에폽토시스 를 유도하여 생장을 억제시키는 것을 발표하였다[29]. 이 같은 에폽토시스에 의한 종양억제 효과는 종양괴사인자(TNF-a)와 관련이 있다. 즉, 종양괴사인자는 면역조절에 1차적인 기능을 하며, 에폽토시스성 세포사멸(apoptotic cell death), 발열 (fever), 악액질(cachexia), 염증을 유발하는 주요한 사이토카 인(cytokine) 이다[16]. 그러나 최근 종양괴사인자는 염증관련 질병의 중요 인자일 뿐만 아니라 혈관신생인자, matrix metal- 
loproteinases (MMPs)와 같은 인자생성을 유도하여 내인성 종 양촉진인자(endogenous tumor promotor)의 하나로 작용할 수 있다는 연구결과도 발표되었다[25]. 또한 Mooer 등은 종양 괴사인자가 결여된 마우스에서 피부암세포의 발생이 적어 종 양괴사인자가 종양초기 단계에 중요한 역할을 한다고 보고하 였다[19]. 버섯의 다당류는 면역강화(immunopotentiation)뿐 만 아니라 종양세포에 직접적인 영향을 주어 사멸시키는 것으 로 알려지고 있다[28]. 그러나, 가장 핵심적인 역할을 하는 사 이토카인인 종양괴사인자의 조직 내 농도와 암세포의 억제 효과를 전자현미경적으로 확인한 연구는 이루어지지 않았다. 따라서 본 연구에서는 영지버섯(Ganoderma lucidum) 균사체에 서 분리 및 정제된 $\beta$-glucan의 종양억제효과를 확인하기 위하 여 Sarcoma-180 종양 세포가 이식된 마우스에 투여 하고, 혈액 과 종양 내 종양괴사인자의 농도 및 억제된 종양세포의 미세 구조를 관찰하였다.

\section{재료 및 방법}

\section{배지}

영지의 균주 보관은 Potato Dextrose Agar (PDA)를 사용하 였으며, 그 외 모든 배지는 $4 \%$ corn starch, 3\% corn steep liquor 그리고 basal medium $(\mathrm{BM})$ 로 조성된 것을 사용하였다. $\mathrm{BM}$ 의 조성은 배지 11 당 $\mathrm{KH}_{2} \mathrm{PO}_{4} 870 \mathrm{mg}, \mathrm{MgSO}_{4} \cdot 7 \mathrm{H}_{2} \mathrm{O} 500$ $\mathrm{mg}, \mathrm{CaCl}_{2} 300 \mathrm{mg}$, $\mathrm{FeSO}_{4} \cdot 7 \mathrm{H}_{2} \mathrm{O} 10 \mathrm{mg}, \mathrm{MnSO}_{4} \cdot 6 \mathrm{H}_{2} \mathrm{O} 7 \mathrm{mg}$, $\mathrm{ZnSO}_{4} \cdot 7 \mathrm{H}_{2} \mathrm{O} 4 \mathrm{mg}$ 및 $\mathrm{CuSO}_{4} \cdot 7 \mathrm{H}_{2} \mathrm{O} 1 \mathrm{mg}$ 으로 구성하여 균주 를 배양하였다.

\section{균주배양}

영지 균사체는 사면 배지로부터 균사체를 분리하여 소량의 액체 배양용 기본배지에 가한 후 균질기(homogenizer, AM-8, Nihonseiki kaisha LTD, Japan)로 균질 화시켜 $100 \mathrm{ml}$ 의 액체 배양용 기본배지가 함유된 $500 \mathrm{ml}$ 배양용 플라스크에 분주하 여 $27^{\circ} \mathrm{C}$ 에서 $120 \mathrm{rpm}$ 으로 6일간 진탕 배양하였다. 본 배양은 액체 배양용 배지가 $100 \mathrm{ml}$ 씩 들어 있는 $500 \mathrm{ml}$ 배양 플라스크 에 균질화 된 종균 배양액 $10 \mathrm{ml}$ 씩 접종하여 $27^{\circ} \mathrm{C}$ 에서 6 일간 진탕 배양하였다. 대량생산을 위한 발효조 배양은 11 플라스 크에서 전 배양된 영지버섯 균사체 $300 \mathrm{ml}$ 를 51 발효조에 working volume 31 의 배지를 넣어 멸균 후 접종하였다. $10 \%$ 의 종균이 접종된 발효조는 교반속도 $300 \mathrm{rpm}$, 통기량 1.0 $\mathrm{vvm}$ 으로 조정한 후 $27^{\circ} \mathrm{C}$ 에서 7 일간 배양하였다.

\section{영지버섯 균사체로부터 $\beta$-glucan (GLP)의 분리}

배양된 영지버섯 균사체로부터 $\beta$-glucan (GLP)은 Fig. 1과 같은 방법으로 분리 및 정제하였다[10]. 7일간 배양된 영지 균 사체 3001 을 수획하여 $\mathrm{NaOH}$ 을 가해 최종 농도 $2 \mathrm{~N}$ 로 조정하 고 18 시간 교반한 후, 빙초산으로 중화시켜 $\mathrm{pH}$ 7.0이 되게 조 정하였다. 중화액은 원심분리기(Sartorius Co., Germany)를

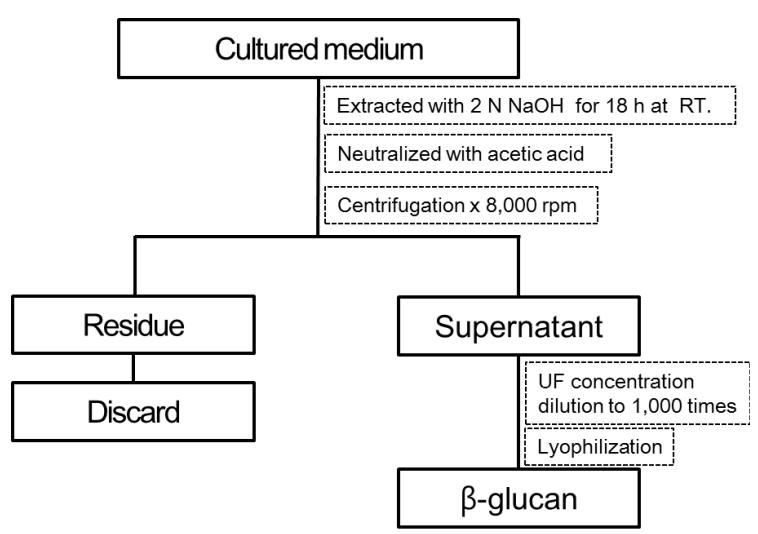

Fig. 1. Purification procedure of $\beta$-glucan (GLP) from Ganoderma lucidum mycelia in the submerged culture.

이용하여 $8,000 \mathrm{rpm}$ 으로 연속 분리하였다. 원심 분리된 상청 액은 한외 여과 장치(ultrafiltration system, Satorius Co., Germany)을 이용하여 분리(cut off molecular size of membrane filter: 10,000$)$ 하였다. 총 volume의 $1 / 10$ 까지 농축한 후 2 배의 물을 첨가하면서 재농축 과정을 반복, 1,000 배 정도 희 석하면서 분자량 10,000 이하의 저분자 물질 및 염 등을 제거하 였다. 농축액은 동결건조기(FD-5508, Ilshin Lab Co., Korea)에 서 건조하여 $\beta$-glucan 시료를 얻었다.

\section{동물 및 종양세포}

마우스는 20-25 g의 ICR계 웅성으로 대한바이오링크(충북 음성, 한국)에서 구입하여 실험실 환경적응을 위하여 1 주간 예비 사육 후 실험을 실시하였다. 본 실험은 순천향대학교 동 물실험윤리위원회의 승인(SCH12_03_01)하에 표준작업 지침 서에 따라 수행되었으며 사육실 조건은 $23 \pm 2{ }^{\circ} \mathrm{C}, 50 \pm 5 \%$ 의 상 대습도와 12 시간의 명암주기를 유지하고 물과 사료(Dhbiolink 사료, 충북음성, 한국)는 자유롭게 섭취하도록 하였다. 실 험동물은 음성군과 양성 투여군으로 나누고 각 군마다 10마리 씩 분리 사육하였다. 암세포인 Sarcoma-180 (KCLB No. 40066) 은 한국세포주 은행으로부터 분양 받아 사용하였다.

\section{Sarcoma-180 육종암 이식 및 종양 저지율 측정}

실험동물의 복강 내에서 7일간 배양된 Sarcoma-180세포를 복수와 함께 취하여 빙냉, 멸균한 생리식염수를 가하여 $100 x$ $g$ 로 5 분간 원심 분리하여 세포를 침전시켰다. 침전된 세포를 빙냉, 멸균된 생리 식염수로 3 회 세척한 후 $1 \times 10^{7}$ cells $/ \mathrm{ml}$ 가 되도록 현탁 하였다. 세포 현탁액 $0.1 \mathrm{ml}\left(1 \times 10^{6}\right.$ cells/mouse) 를 실험동물의 왼쪽 서혜부에 피하 이식하였다. 종양세포를 10 마리씩 군 분리한 마우스에 각각 이식하고 72 시간 후 약물 투여를 시작하였으며, 매일 1 회씩 10 일간 연속하여 복강 내 주사하였다. 대조군에는 같은 양의 생리식염수를, 양성 대조 군에는 polysaccharide-K (PSK, 상품명: Krestin®)을 $20 \mathrm{mg} / \mathrm{k}$ $\mathrm{g}$ 의 농도로, 시험군에는 생리식염수에 현탁 한 시료를 20 
$\mathrm{mg} / \mathrm{kg}$ 씩 복강에 주사하였으며 주사용량은 $0.1 \mathrm{ml}$ 로 하였다. PSK은 담자균류 구름버섯(Trametes versicolor)으로부터 분리 된 $\beta-1,4$ 결합을 주로 갖는 다당체로 $\beta-1,6$ 과 $\beta-1,3$ 분지와 단백 질이 결합된 특징이 있으며, 일본에서 암치료제로 1977년 개 발된 이후 현재까지 세계적으로 활용되고 있는 면역 증강제이 다. 본 연구에서 분리된 $\beta$-glucan (GLP)은 $\beta-1,3$ 결합을 주로 가지며 $\beta-1,6$ 분지가 결합된 특징을 가지고 있다[11]. 종양저지 율의 측정은 종양세포를 서혜부에 이식한지 30 일째 되는 날 실험동물을 희생시켜 고형암을 적출한 후 평균 종양 중량을 얻고, 생리식염수를 투여한 대조군과 비교하여 종양저지 백분 율(percent inhibition ratio = I. R., \%)을 계산하였다.

$$
\begin{aligned}
& \text { I.R. }(\%)=\frac{C w-T w}{C w} \times 100 \\
& \mathrm{Cw}=\text { 대조군의 평균 종양 무게 } \\
& \mathrm{Tw}=\text { 시험군의 평균 종양 무게 }
\end{aligned}
$$

\section{혈액 및 종양 내 종양괴사인자(TNF-a)의 측정}

$\beta$-glucan을 마우스 복강 내 주사하고, 혈액 및 tumor mass 내 종양괴사인자(TNF-a)의 정량은 multiple antibody sandwich 원리를 이용한 solid-phase ELISA 방법으로 측정하였다. 마우스의 시험군과 대조군의 심장에서 혈액을 채취한 후 $4^{\circ} \mathrm{C}$ 에서 $4,000 \mathrm{rpm}$ 으로 15 분간 원심 분리하여 혈장을 분리하였 다. 종양세포가 이식한지 30 일차에 마우스를 치사시키고, 서 혜부의 종양덩어리와 간을 적출하여 조직 균등분산기(tissue homogenizer)로 균등분쇄 한 다음 $4,000 \mathrm{rpm}$ 으로 15 분간 원 심 분리하여 세포 및 조직현탁액을 얻었다. 분리된 혈장과 조 직현탁액들은 $-70^{\circ} \mathrm{C}$ 에서 동결 보관하면서 실험에 이용하였다. 종양괴사인자의 정량은 Quantikine® Mouse TNF-a Immunoassay Kit (R\&D systems, MTA00B, USA)을 사용하였다. 측정방법은 monoclonal anti-TNF-a가 pre-coated되어 있는 96-well microtiter plate에 $50 \mu \mathrm{l}$ 의 희석용 완충액을 넣고 GLP 로 활성화된 마우스의 혈청 또는 조직분쇄 상징액을 $50 \mu 1$ 를 가하여 시험 시료 내에 존재하는 mouse TNF-a와 결합시켰다. 시료를 첨가한 후 $37^{\circ} \mathrm{C}$ 에서 2시간 동안 반응시킨 후, 수세용 완충액으로 4 회 수세하여 결합되지 않은 물질을 제거시켰다. 다시 peroxidase-conjugated polyclonal anti-TNF-a (HRPconjugate)를 첨가하여 이미 결합된 TNF- $a$ 와 결합시켰다. 37 ${ }^{\circ} \mathrm{C}$ 에서 1 시간 동안 반응시킨 후, 결합하지 않은 물질을 제거하 기 위하여 plate를 4 회 수세하고, 기질액인 hydrogen peroxide 와 발색제인 tetramethylbenzidine (TMB)를 가하여 peroxidase와 촉매 반응을 유도시켜 발색시켰다. 효소의 반응 정지 시약인 $1 \mathrm{M}$ 의 sulfuric acid $100 \mu \mathrm{l}$ 를 가하여 반응을 정지시켰 다. 반응 정지 후 실온에서 10 분 동안 방치하고 30 분 이내에 ELISA reader (Fluostar OPTIMA, BMG Labtech, Australia)를 이용하여 $450 \mathrm{~nm}$ 에서 흡광도를 측정하였다. 시료 속의 TNF-a 양은 표준 TNF- $a$ 의 농도의 흡광도를 이용하여 얻어진 표준
직선으로부터 계산하였다.

\section{Sarcoma-180 육종암의 미세구조 관찰}

Sarcoma-180 육종암을 마우스 서혜부에 이식 후 10일 간격 으로 GLP를 복강 투여하여 30 일 후 대조군과 시험군의 육종 암 미세구조를 투과전자현미경(Transmission electron microscope, TEM)으로 관찰하였다. GLP를 처리한 종양세포를 $2 \%$ glutaraldehyde에 전 고정하고 $1 \% \mathrm{OsO}_{4}$ 로 후 고정 하였다. 조직의 초박절편을 위하여 $50,60,70,90,95,100 \%$ ethanol로 탈수 후 propylene oxide로 치환하고 epon block을 제조하였 다. Epon block을 diamond knife로 $70 \mathrm{~nm}$ 두께로 초박절편한 다음 lead nitrate로 염색하여 TEM (JEOL-1010, Japan)으로 $80 \mathrm{kV}$ 에서 관찰하였다.

\section{통계처리}

통계 분석은 Student's $t$-test(두 집단간 등분산 검정)로 $p<$ 0.05 수준에서 통계적 유의성을 분석하였으며, 데이터는 평균 \pm 표준오차로 표현하였다.

\section{결과 및 고찰}

\section{Sarcoma-180 육종암 저지율}

항암활성을 검색하기 위해 시료를 Sarcoma-180이 서혜부 에 이식된 마우스에 $20 \mathrm{mg} / \mathrm{kg}$ 의 용량으로 1일 1회씩 10 일 동안 복강으로 투여하였다. 약물투여가 완료된 날로부터 30일 째에 고형암을 적출하여 암증식 저지율을 측정한 결과, Fig. 2 와 같다. 실험 결과 GLP는 $71.4 \%$ 의 암억제율을 보였으며, 양성 대조군인 면역항암제 polysaccharide-K (PSK, a proteinbound $\beta$-(1-3) glucan type polysaccharide isolated from Trametes versicolor)는 $50.3 \%$ 의 항암활성을 나타내어 GLP보다

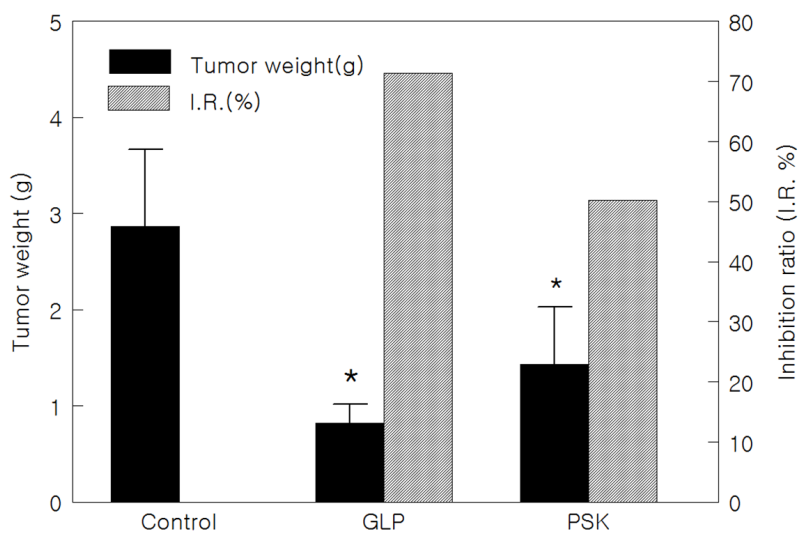

Fig. 2. Antitumor activity of GLP purified from the mycelium of $G$. lucidum in mice previously inoculated with Sarcoma-180. Data represent the means of ten animals per treatment group. GLP; $\beta$-glucan purified from $G$. lucidum ${ }^{*} p<0.05$, compared to control group. 
낮은 항암활성을 보였다.

\section{혈액 및 종양 내 종양괴사 인자(TNF-a) 정량}

Monokine인 종양괴사인자는 항암활성을 중재하는 단백질 로서 활성화된 대식세포에 의해서 분비된다. 또한 종양괴사인 자는 호중구 세포의 기능조절, myeloid cell 분화촉진, B 세포 의 증식 및 대식세포 등의 활성 등을 유발시킬 수 있다. 특히 종양괴사인자는 정상세포와 무관하게 종양, 살모넬라증(salmonellosis), 그리고 바이러스에 감염된 세포를 인식하고 에폽 토시스 또는 세포괴사(necrosis) 시킬 수 있는 능력이 있다[16]. 따라서 GLP에 의한 종양괴사인자의 생성 촉진의 정량은 생체 내 면역 반응을 확인하는 지표가 될 수 있다. GLP에 의한 종양 괴사 인자의 생성 촉진은 Fig. 3 에서와 같이 혈중 종양괴사인 자의 농도가 $57.3 \mathrm{pg} / \mathrm{ml}$ 로 대조군 $(4.6 \mathrm{pg} / \mathrm{ml})$ 보다 12.4 배 증 가하였다. 양성 대조군인 PSK은 $40.3 \mathrm{pg} / \mathrm{ml}$ 로 대조군보다 8.7 배 증가하였으며 GLP에 의한 종양괴사인자생성이 PSK보다 더 높은 것을 확인하였다. Sarcoma-180이 이식된 마우스에 $\mathrm{GLP}$ 를 복강 투여 $(20 \mathrm{mg} / \mathrm{kg})$ 시 혈중 종양괴사인자의 농도는 $115.8 \mathrm{pg} / \mathrm{ml}$ 로 음성 대조군인 생리식염수를 투여하였을 때 보다 $(36.3 \mathrm{pg} / \mathrm{ml}) 3.2$ 배 높은 종양괴사인자를 생성하였다(Fig. 3). Sarcoma-180이 이식된 마우스에 GLP를 복강 투여(20 $\mathrm{mg} / \mathrm{kg}$ ) 시 Sarcoma-180 tumor mass 내 종양괴사인자의 농도 는 $269.6 \mathrm{pg} / \mathrm{ml}$ 로 대조군보다 2.6배, 양성 대조군인 PSK보다 1.6배 높은 종양괴사인자농도를 나타내었다(Fig. 4). 또한 간 (liver) 조직 내 종양괴사인자의 농도는 $1,032.2 \mathrm{pg} / \mathrm{ml}$ 로 음성 대조군보다 1.9 배, 양성 대조군인 PSK보다 1.3 배 높은 종양괴 사인자농도를 보였다(Fig. 4). 따라서, 영지버섯에서 추출된 $\mathrm{GLP}$ 는 간조직과 암세포 덩어리 부위에 종양괴사인자농도를

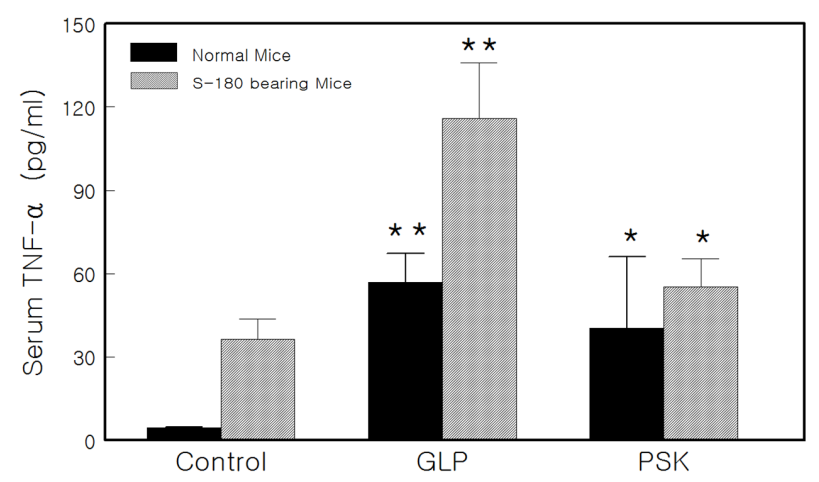

Fig. 3. TNF-a concentration in the serum of Sarcoma 180 tumor-bearing mice. Mice were treated with $20 \mathrm{mg} / \mathrm{kg}$ GLP by intraperitoneal injection for 10 days. TNF-a concentration in the serum of mice was measured by ELISA at 30 days after GLP-treatment. Data are expressed as the TNF- $a$ concentration $(\mathrm{pg} / \mathrm{ml})$ in mouse serum and are shown as the mean of ten animals per treatment group. ${ }^{*} p<0.05$ and ${ }^{* *} p<0.01$, compared to control group.

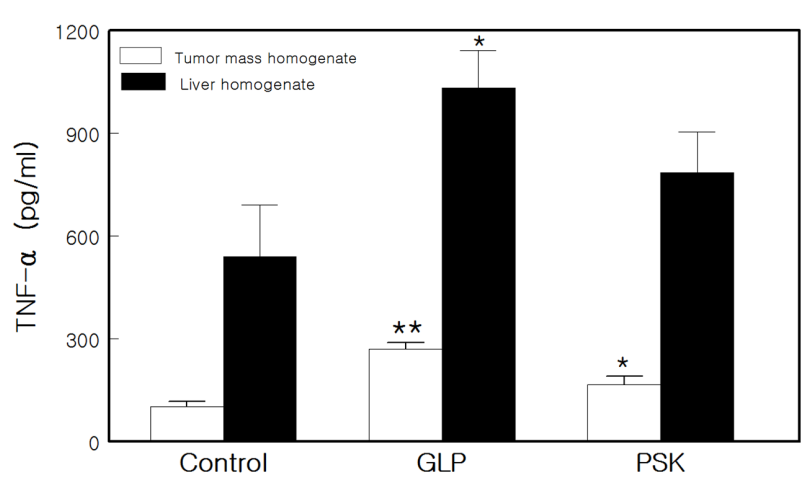

Fig. 4. TNF-a concentration in the tumor mass (white bars) and liver mass (black bars) after treated with GLP in Sarcoma 180 tumor cell-bearing mice. Sarcoma180-bering mice were treated with $20 \mathrm{mg} / \mathrm{kg}$ GLP and PSK (positive control) by intraperitoneal injection for 10 days. The Sarcoma180 cell mass and liver mass were removed from mice at 30 days after administration, and homogenized with PBS. TNF-a concentration was determined by ELISA. Data represent the means of ten animals per treatment group. ${ }^{*} p<0.05$ and ${ }^{* *} p<0.01$, compared to control group.

유도하여 종양 세포를 억제하는 것으로 여겨진다.

\section{Sarcoma-180 육종암의 미세구조}

Sarcoma-180 육종암 세포주를 마우스 서혜부에 접종하고, 면역증강제 $\mathrm{GLP}$ 를 복강 투여 시 나타나는 종양세포의 생장억 제를 미세구조 수준에서 확인하였다. 먼저 마우스 서혜부로 이식된 억제되지 않은 정상적인 Sarcoma-180 육종암 덩어리 의 세포 구조는 Fig. 5 와 같이 정상적인 세포구조와 세포소기 관이 보였으며, 염색질은 균일한 분포를 나타내었다. 보통의 세포는 핵질과 세포질의 비율이 1:1인 반면, Sarcoma-180 세포 의 경우 세포질에 대한 핵질의 크기(N/C ratio)가 대조군 보다 큰 것으로 나타났는데, 이는 미분화 종양세포들의 주요 특징 가운데 하나이다(Fig. 5A). 또한 Sarcoma-180 세포의 전자현미 경적 양상 가운데 가장 특징적인 것 중 하나로 세포질내의 미세섬유(micro fiber, MF)가 나타났다(Fig. 5B). 이 같은 구조 는 약 $100 \mathrm{~nm}$ 크기의 bundle 형태로 다수 존재하였으며, 이는 보통 세포가 갖는 세포 골격을 유지하는 소 구조로써 주로 세포질막 주변에 존재하는 것과는 다르게 핵 주변에서도 많이 보였다. 핵막의 경우 2 중막이 선명하게 보였으며, 규칙성을 갖고 뚜렷하게 유지하였다(Fig. 5B). 핵 속에는 상대적으로 큰 인(nucleolus)이 존재하였으며, 이는 암세포가 증식하기 위해 단백질 합성(protein synthesis)이 활발한 것으로 여겨진다. GLP가 투여된 종양세포 역시 Fig. $6 \mathrm{~A}, \mathrm{~B}$ 와 같이 상대적으로 큰 핵이 관찰되었다. 특히 세포의 에폽토시스에서 전형적으로 보여지는 염색질 응축이 관찰되었으며, 특히 핵막 변연부에 응 축 현상이 뚜렷하였다. 이는 정상적인 암세포의 핵이 DNAases 와 RNAases에 의해 염색질이 먼저 분해되고, 핵이 분해되기 

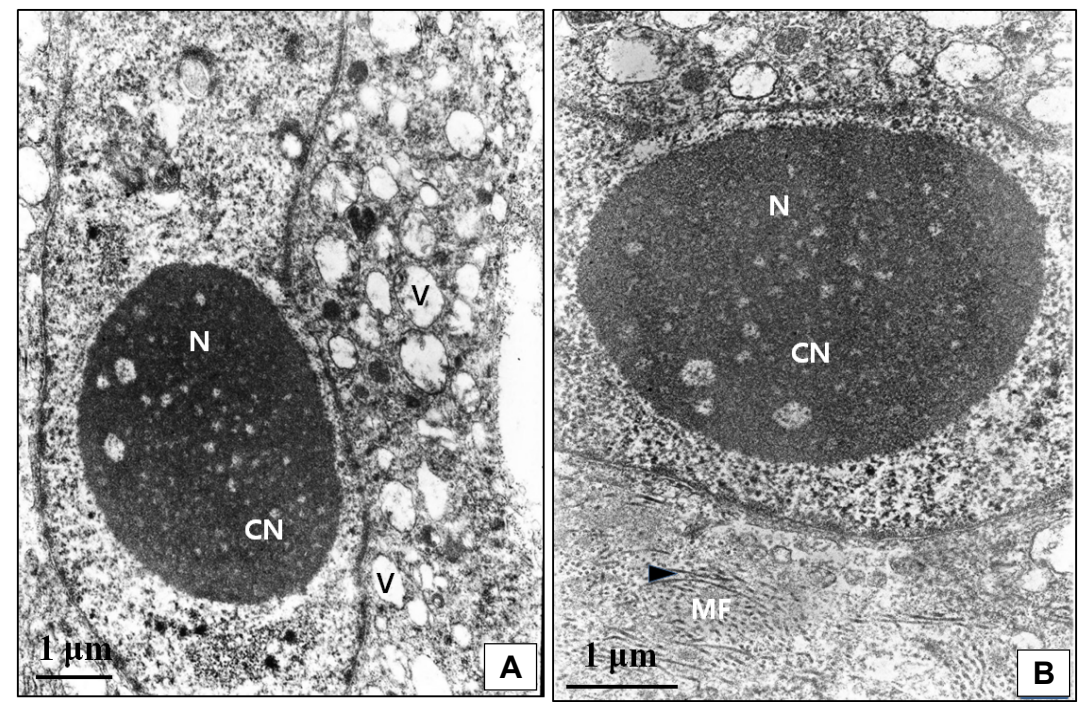

Fig. 5. Transmission electron micrograph of the excisioned-Sarcoma 180 tissue after treated with GLP in Sarcoma-180 tumor-bearing mice. Mice were treated with $20 \mathrm{mg} / \mathrm{kg}$ GLP by intraperitoneal injection for 10 days. $5 \mathrm{~A}$; Sarcoma-180 tumor cells of negative control show many vacuolization (V) in the cytoplasm, and abnormal structures in the plasma membrane and organelles. 5B; Sarcoma-180 tumor cells treated with GLP show a characteristic chromatin in large nucleus $(\mathrm{CN})$, and micro fiber (MF) in the cytoplasm. A; $x 6,000, B ; x 8,000$.
위한 전 단계이다. Kim 등[8] 은 $\beta$-glucan을 결장암세포에 투 여한 후 TUNEL assay을 통해 세포의 염색질 응축과 apoptotic body이 생성되는 형태변화를 관찰하고 보고한바 있다. 핵막은 특징적으로 뭉쳐져(characteristic clustering) 불규칙한 모양을 나타내었다(Fig. 6B). 특히 핵이 팽창되어 있으며, 이는 물질대사의 양적 증대를 위한 것인지, 아니면 핵질의 유출에 따른 물질대사적 평형이 깨져 일어난 것인지에 대해서는 불분 명하나, 또한 핵 주위의 공간은 팽창되고 핵막의 일부가 붕괴 되는 것도 관찰되었다. 전반적인 세포의 형태는 정상세포보다 세포의 크기가 크며, 세포소기관의 팽창과 함께 상대적으로 정상세포보다 적었다. 세포질막은 표면이 매우 불규칙하여 일 부 붕괴된 형태도 관찰되었다. 육종암 덩어리내의 세포 내 핵 은 여러 가지 형태로 존재하였다(Fig. 6C). 정상 세포의 핵질은 핵 내에 전체적으로 분산되어 존재하나, GLP의 투여에 따라
증식이 억제된 종양 덩어리의 전자현미경 사진은 핵질이 2분 화, 다분화 및 핵막 주변에 응집 분산된 형태 등이 관찰되었다. 이와 같이 핵질의 응집은 세포의 에폽토시스 시 전형적으로 갖는 형태이며, 따라서 Sarcoma-180세포가 에폽토시스 되면 서 발생되는 현상으로 볼 수 있다. 또한 일반적인 세포의 미토 콘드리아(mitochondria) 형태는 장축으로 신장된 특징적 구조 를 갖고 반면 Sarcoma-180의 경우 round하게 나타났다. 이와 같은 결과는 Sarcoma-180 세포가 에폽토시스 되면서 세포 swelling과 함께 일어난 결과로 여겨지며 cristae 역시 일반적 인 미토콘드리아와는 달리 장축과 같은 방향으로 배열되었다 (Fig. 6C). 또한 일반적인 조직의 세포간극은 매우 정교하게 체계를 갖고 배열 및 유지 되는 반면, Sarcoma-180 세포 간 연결하는 세포간극은 매우 불규칙하게 보였다. 이는 세포와 세포간의 유전 및 물질대사적 통제가 부정확하게 일어나는

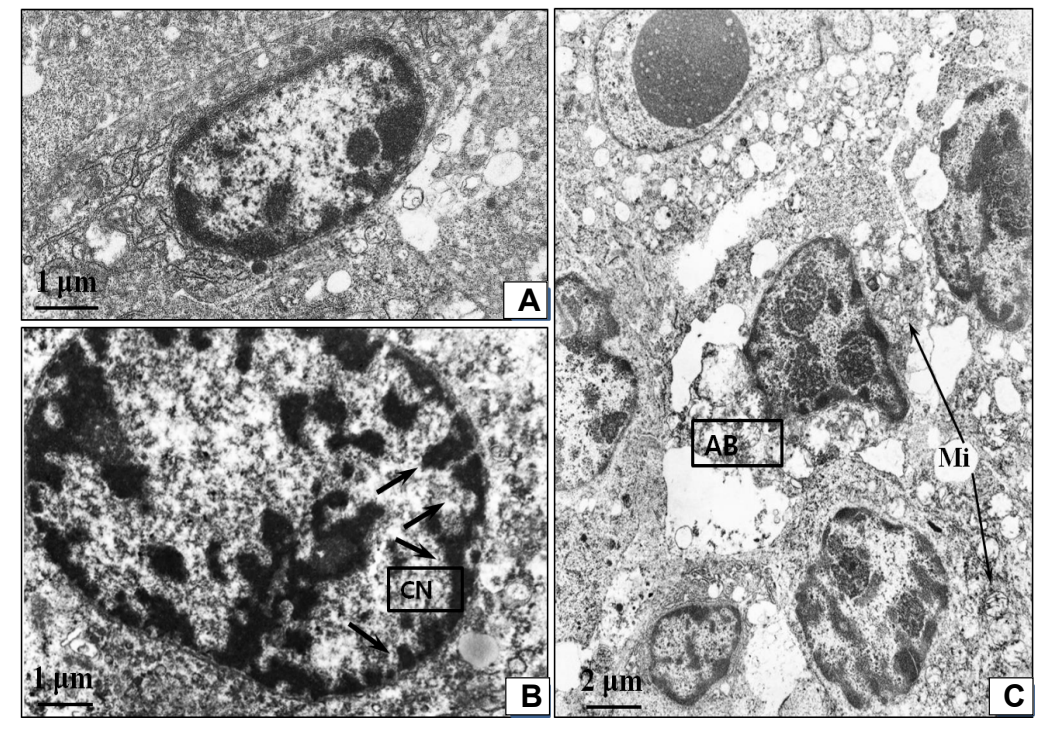

Fig. 6. Transmission electron micrograph of the explanted-tumor cell after treated with GLP in Sarcoma 180-bearing mice. Sarcoma-180 tumor cells treated with $20 \mathrm{mg} / \mathrm{kg}$ of GLP for 10 days. $6 \mathrm{~A}(\mathrm{x} 6,000)$ and $6 \mathrm{~B}(\mathrm{x} 8,000)$ illustrate the SEM images of the characteristic chromatin fragmentation appears with condensation of the nucleus ( $\mathrm{CN}$, arrows). Also, condensation of the nucleus is clearly different from its normal organization. $6 \mathrm{C}$ $(\times 3,000)$ shows the tumor cells showed typical apoptotic morphology as evidenced by blebs of cell membrane and fragmentation of the nuclear compartment. $\mathrm{AB}$; apoptotic bodies. Arrows; mitochondria (Mi). 
것을 의미하며, 세포 분열 역시 통제 받지 않은 상태로 진행된 것으로 보여 진다.

\section{감사의 글}

본 연구는 순천향대학교 학술연구비의 일부 지원으로 수행 하였음.

\section{References}

1. Boh, B., Berovic, M., Zhang, J. and Zhi-Bin, L. 2007. Ganoderma lucidum and its pharmaceutically active compounds. Biotechnol Annu Rev 13, 265-301.

2. Cao, L. Z. and Lin, Z. B. 2002. Regulation on maturation and function of dendritic cells by Ganoderma lucidum polysaccharides. Immunol Lett 83, 163-169.

3. Cao, Q. Z. and Lin, Z. B. 2006. Ganoderma lucidum polysaccharides peptide inhibits the growth of vascular endothelial cell and the induction of VEGF in human lung cancer cell. Life Sci 78, 1457-1463.

4. Chien, C. M., Cheng, J. L., Chang, W. T., Tien, M. H., Tsao, C. M., Chang, Y. H., Chang, H. Y., Hsieh, J. F., Wong, C. H. and Chen, S. T. 2004. Polysaccharides of Ganoderma lucidum alter cell immunophenotypic expression and enhance CD56+ NK-cell cytotoxicity in cord blood. Bioorg Med Chem 12, 5603-5609.

5. Chow, L. W., Lo, C. S., Loo, W. T., Hu, X. C. and Sham, J. S. 2003. Polysaccharide peptide mediates apoptosis by up-regulating p21 gene and down-regulating cyclin D1 gene. Am J Chin Med 31, 1-9.

6. Efferth, T., Li, P. C., Konkimalla, V. S. and Kaina, B. 2007. From traditional Chinese medicine to rational cancer therapy. Trends Mol Med 13, 353-361.

7. Eo, S. K., Kim, Y. S., Lee, C. K. and Han, S. S. 1999. Antiherpetic activities of various protein bound polysaccharides isolated from Ganoderma lucidum J Ethnopharmacd 68, 175-181.

8. Kim, M. J., Hong, S. Y., Kim, S. K., Cheong, C., Park, H. J., Chun, H. K., Jang, K. H., Yoon, B. D., Kim, C. H. and Kang, S. A. 2009. B-Glucan enhanced apoptosis in human colon cancer cells SNU-C4. Nutr Res Pract 3, 180-184.

9. Kroemer, G., Galluzzi, L., Vandenabeele, P., Abrams, J., Alnemri, E. S., Baehrecke, E. H., Blagosklonny, M. V., El-Deiry, W. S., Golstein, P., Green, D. R., Hengartner, M., Knight, R. A., Kumar, S., Lipton, S. A., Malorni, W., Nuñez, G., Peter, M. E., Tschopp, J., Yuan, J., Piacentini, M., Zhivotovsky, B. and Melino, G. 2009. Classification of cell death: recommendations of the Nomenclature Committee on Cell Death. Cell Death Differ 16, 3-11.

10. Gao, Y., Zhou, S., Wen, J., Huang, M. and Xu, A. 2002. Mechanism of the antiulcerogenic effect of Ganoderma lucidum polysaccharides on indomethacin-induced lesions in the rat. Life Sci 72, 731-745.

11. Han, M. D., Han, Y. S., Hyun, S. H. and Shin, H. W. 2008.
Solubilization of water-insoluble beta-glucan isolated from Ganoderma lucidum J Environ Biol 29, 237-242.

12. Hsu, M. J., Lee, S. S. and Lin, W. W. 2002. Polysaccharide purified from Ganoderma lucidum inhibits spontaneous and Fas-mediated apoptosis in human neutrophils through activation of the phosphatidylinositol 3 kinase/Akt signaling pathway. J Leukoc Biol 72, 207-216.

13. Hsu, M. J., Lee, S. S., Lee, S. T. and Lin, W. W. 2003. Signaling mechanisms of enhanced neutrophil phagocytosis and chemotaxis by the polysaccharide purified from Ganoderma lucidum Br J Pharmacol 139, 289-298.

14. Li, G., Kim, D. H., Kim, T. D., Park, B. J., Park, H. D., Park, J. I., Na, M. K., Kim, H. C., Hong, N. D., Lim, K., Hwang, B. D. and Yoon, W. H. 2004. Protein-bound polysaccharide from Phellinus linteus induces G2/M phase arrest and apoptosis in SW480 human colon cancer cells. Cancer Lett 216, 175-181.

15. Lin, Y. L., Liang, Y. C., Lee, S. S. and Chiang, B. L. 2005. Polysaccharide purified from Ganoderma lucidum induced activation and maturation of human monocyte-derived dendritic cells by the NF-kappa B and p38 mitogen-activated protein kinase pathways. J Leukoc Biol 78, 533-543.

16. Locksley, R. M., Killeen, N., Lenardo, M. J. 2001. The TNF and TNF receptor superfamilies: integrating mammalian biology. Cell 104, 487-501.

17. Maruyama, H., Yamazaki, K., Murofushi, S., Konda, C. and Ikekawa, T. 1989. Antitumor activity of Sarcodon aspratus (Berk.) S. Its and Ganoderma Iucidum (Fr.) Karst. J Pharmacobiodyn 12, 118-123.

18. el-Mekkawy, S., Meselhy, M. R., Nakamura, N., Tezuka, Y., Hattori, M., Kakiuchi, N., Shimotohno, K., Kawahata, T. and Otake, T. 1998. Anti-HIV-1 and anti-HIV-1-protease substances from Ganoderma lucidum Phytochemistry 49, 16511657.

19. Moore, R. J., Owens, D. M., Stamp, G., Arnott, C., Burke, F., East, K. 1999. Mice deficient in tumor necrosis factor-a are resistant to skin carcinogenesis. Nat Med 5, 828-831.

20. Park, E. J., Ko, G., Kim, J. and Sohn, D. H. 1997. Antifibrotic effects of a polysaccharide extracted from Ganoderma lucidum, glycyrrhizin, and pentoxifylline in rats with cirrhosis induced by biliary obstruction. Biol Pharm Bull 20, 417-420.

21. Shiao, M. S. 2003. Natural products of the medicinal fungus Ganoderma lucidum occurrence, biological activities, and pharmacological functions. Chem Rec 3, 172-180.

22. Sliva, D. 2003. Ganoderma lucidum (Reishi) in cancer treatment. Integr Cancer Ther 2, 358-364.

23. Sliva, D. 2004. Cellular and physiological effects of Ganoderma lucidum (Reishi). Mini Rev Med Chem 4, 873-879.

24. Wang, Y. Y., Khoo, K. H., Chen, S. T., Lin, C. C., Wong, C. H. and Lin, C. H. 2002. Studies on the immuno-modulating and anti-tumor activities of Ganoderma lucidum (Reishi) polysaccharides: Functional and proteomic analyses of a fucose-containing glycoprotein fraction responsible for the activities. Bioorg Med Chem 10, 1057-1062.

25. Waterston, A. and Bower, M. 2004. TNF and cancer: good or bad? Cancer Ther 2, 131-148. 
26. Wasser, S. P. 2002. Medicinal mushrooms as a source of antitumor and immunomodulating polysaccharides. Appl Microbiol Biotechnol 60, 258-274.

27. Wu, T. S., Shi, L. S. and Kuo, S. C. 2001. Cytotoxicity of Ganoderma lucidum triterpenes. I Nat Prod 64, 1121-1132.

28. Zaidman, B. Z., Yassin, M., Mahajna, J. and Wasser, S. P.
2005. Medicinal mushroom modulators of molecular targets as cancer therapeutics. Appl Microbiol Biotechnol 67, 453-468.

29. Zhang, M., Chiu, L. C., Cheung, P. C. and Ooi, V. E. 2006. Growth-inhibitory effects of a $\beta$-glucan from the mycelium of Poria cocos on human breast carcinoma MCF-7 cells: Cell cycle arrest and apoptosis induction. Oncol Rep 15, 637-643.

초록 : 영지(Ganoderma lucidum)의 $\beta$-Glucan에 의한 Sarcoma-180 육종암 생장 억제

한만덕* · 김용현 · 김완종

(순천향대학교 자연과학대학 생명과학과)

버섯 다당류 $\beta$-glucan의 항암 활성을 확인하기 위하여 영지균사체로부터 단백다당류(GLP)를 분리하고 Sarcoma-180 육종암을 이식시킨 마우스에 복강 투여하여 항암활성을 확인하였다. 육종암이 서혜부에 이식된 마우 스에 GLP를 $20 \mathrm{mg} / \mathrm{kg}$ 의 농도로 10 일간 복강투여 한 후 30일차에 확인한 결과, Sarcoma-180 육종암은 대조군 대비 $71.4 \%$ 억제되었으며, 마우스의 혈청, 종양조직 및 간조직 내의 TNF- $a$ 의 농도는 대조군보다 높게 나타났다. 따라서 GLP는 생체 내 TNF- $a$ 의 양적증가를 유도하며, 종양괴사 또는 에폽토시스와 연관된 육종암의 생장억제가 확인되었다. 이때 생장이 억제된 육종암 세포의 미세구조를 관찰한 결과, 상대적으로 큰 핵과 세포의 에폽토시스 에서 전형적으로 보여지는 염색질 응축이 관찰되었으며, 핵막은 특징적으로 뭉쳐져 불규칙한 모양을 나타내었다. 따라서 영지에서 분리된 GLP는 종양 세포의 에폽토시스를 유도하여 종양의 성장을 억제하는 것으로 여겨진다. 